\title{
UPAYA MENINGKATKAN AKTIVITAS BELAJAR IPS MELALUI MODEL PEMBELAJARAN MAKE A MATCH PADA SISWA KELAS VIII SMP NEGERI 2 TALUDITI TAHUN AJARAN 2017/2018
}

\author{
Farid R. Paneo \\ SMP Negeri 2 Taluditi Kab. Pohuwato \\ farid@gmail.com
}

Received: 25 November 2018; Revised: 1 Desember 2018; Accepted: 5 Desember 2018

\begin{abstract}
ABSTRAK
Tujuan dari Penelitian Tindakan Kelas ini adalah dengan penerapan model pembelajaran Make a Match untuk meningkatkan aktivitas dalam pembelajaran IPS. Subjek penerima tindakan adalah siswa kelas VIII SMP Negeri 2 Taluditi Tahun Ajaran 2017/2018 yang berjumlah 34 siswa dan subyek pelaksana adalah peneliti. Jenis penelitian ini adalah Penelitian Tindakan Kelas (PTK). Teknik pengumpulan data yang digunakan dalam penelitian ini adalah lembar observasi, catatan dilapangan/pada waktu melaksanakan tidakan, lembar pedoman wawancara, lembar penilaian individu setelah mengikuti pembelajaran, dokumentasi. Prosedur dalam penelitian ini ada empat tahap yaitu perencanaan, pelaksanaan, pengamatan, dan refleksi. Penelitian dilakukan dengan dua siklus dimana tiap siklus dilakukan dalam dua kali pertemuan yang bertujuan untuk memperoleh data peningkatan aktivitas dalam pembelajaran IPS siswa. Hasil Penelitian menunjukkan bahwa sebelum tindakan diperoleh rata-rata tingkat aktivitas siswa sebesar $15 \%$. Pada siklus I tingkat rata-rata aktivitas siswa meningkat menjadi 51,17\%. Pada siklus II tingkat rata-rata aktivitas meningkat menjadi $84,72 \%$. Hal ini berasti peningkatan aktivitas siswa mencapai indikator yakni $85 \%$. Berdasarkan data hasil Penelitian Tindakan Kelas tersebut maka dapat disimpulkan bahwa dengan penerapan model pembelajaran Make a Match dapat meningkatkan aktivitas dalam pembelajaran IPS pada siswa kelas VIII SMP Negeri 2 Taluditi Tahun Ajaran 2017/2018. Hal ini karena model pembelajaran kooperatif tipe Make a Match (mencari pasangan) mengandung unsur permainan sehingga dapat meningkatkan aktivitas belajar siswa baik secara kognitif maupun fisik. Kata kunci: Aktivitas belajar, Model pembelajaran Make a Mtach, dan Pembelajaran IPS
\end{abstract}

\section{PENDAHULUAN}

Pendidikan merupakan segala situasi hidup yang mempengaruhi pertumbuhan individu sebagai pengalaman belajar yang berlangsung dalam segala lingkungan dan sepanjang hidup. Pendidikan merupakan proses mengubah tingkah laku anak didik agar menjadi manusia dewasa yang mampu hidup mandiri dan berada. Pendidikan adalah menananmkan tingkah laku atau kebiasaan yang baru. (Soekidjo, 2003:68).

Pendidikan berusaha mengembangkan seluruh aspek kepribadian dan kemampuan manusia, baik dilihat dari aspek kognitif, apektif, dan psikomotor. Pendidikan diarahkan untuk dapat menciptakan sumber yang berkualitas dengan segala aspeknya. Dengan demikian perlu diciptakan sistem pembelajaran yang berkualitas. Sejalan perkembangan masyarakat dewasa ini pendidikan banyak menghadapi berbagai 


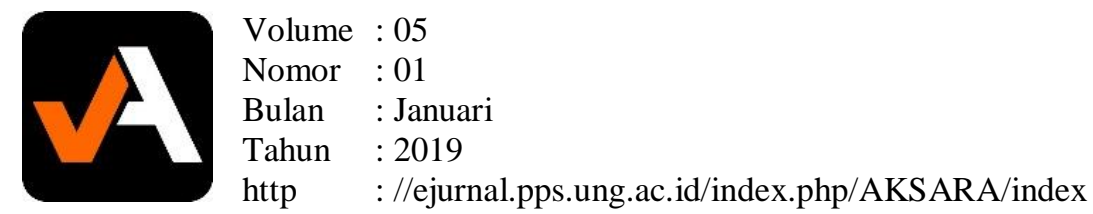

tantangan, salah satunya berkenaan dengan peningkatan mutu pendidikan. Dalam rangka meningkatkan mutu pendidikan dengan mengacu pada tujuan pendidikan nasional Indonesia. Sebagaimana yang tercantum dalam UU No. 11 tahun 2006 Pasal 4 merumuskan, Tujuan pendidikan nasional yaitu Mencerdaskan kehidupan bangsa dan mengembangkan manusia seutuhnya. Yaitu manusia yang beriman dan bertaqwa kepada Tuhan YME dan berbudi pekerti luhur, memiliki keterampilan kesehatan jasmani dan rohani, kepribadian mantap dan mandiri serta rasa tanggung jawab kemasyarakatan dan kebangsaan.

Salah satu upaya untuk meningkatkan mutu pendidikan adalah dengan cara memperbaiki proses belajar mengajar. Proses pembelajaran merupakan suatu hal yang penting dalam sebuah pendidikan karena interaksi pembelajaran adalah kegiatan inti pembelajaran yang dapat menjadi sarana transfer keilmuan dari guru dengan siswa yang terstruktur dan terencana, sehingga bisa menjadikan siswa paham akan materi pelajaran yang disampaikan oleh guru.

Kenyataan dalam pendidikan sekarang ini terdapat banyak masalah yang dihadapi pada saat proses pembelajaran. Salah satu masalah dari berbagai masalah yang terdapat dalam proses pembelajaran adalah kurangnya aktivitas belajar siswa.

Begitu pula pelaksanaan pembelajaran yang dilakukan di SMP Negeri 2 Taluditi belum berlangsung dengan sempurna, masih ada beberapa kekurangan sehingga menyebabkan aktivitas belajar tidak maksimal, seperti pemanfaatan fasilitas yang ada disetiap ruang kelas yang ada di SMP Prawira Marta belum maksimal, penggunaan model pembelajaran yang tidak bervariasi, kurangnya aktivitas belajar siswa dalam kegiatan pembelajaran.

Penggunaan model pembelajaran yang tidak sesuai atau kurang tepat sangat mempengaruhi aktivitas belajar siswa dalam pembelajaran IPS sehingga siswa tidak dapat dengan mudah memahami dan menguasai materi yang disampaikan. Maka penggunaan model pembelajaran bagi guru merupakan hal yang cukup penting dalam peningkatan aktivitas belajar siswa. Memperhatikan tujuan dan esensi pendidikan IPS, sebaiknya penyelenggaraan pembelajaran IPS mampu mempersiapkan, membina, dan membentuk kemampuan siswa yang menguasai pengetahuan, sikap, nilai, dan kecakapan dasar yang diperlukan bagi kehidupan di masyarakat.

Mengenai rendahnya aktivitas belajar siswa dalam pembelajaran IPS pada siswa kelas VIII SMP Negeri 2 Taluditi, maka salah satu pemecahan masalah yang dapat dilakukan oleh adalah merubah proses pembelajaran yang digunakan kearah pembelajaran yang mampu memberi peluang dan mampu meningkatkan aktivitas belajar siswa dalam proses pembelajaran yaitu salah satunya penerapan model pembelajaran Make a Match. Hal ini karena model pembelajaran kooperatif tipe Make a Match (mencari pasangan) mengandung unsur permainan sehingga dapat meningkatkan aktivitas belajar siswa baik secara kognitif maupun fisik.

Tujuan diadakan penelitian ini adalah untuk mengetahui apakah model pembelajaran Make a Match dapat meningkatkan aktivitas belajar siswa dalam mata pelajaran IPS pada siswa kelas VIII SMP Negeri 2 Taluditi Tahun Ajaran 2017/2018.

\section{METODE PENELITIAN}

Penelitian ini adalah penelitian tindakan kelas (PTK). PTK adalah salah satu jenis penelitian tindakan yang dilakukan oleh guru untuk meningkatkan kualitas 


$\begin{array}{ll}\text { Volume } & : 05 \\ \text { Nomor } & : 01 \\ \text { Bulan } & : \text { Januari } \\ \text { Tahun } & : 2019 \\ \text { http } & : / / \text { jurnal.pps.ung.ac.id/index.php/AKSARA/index }\end{array}$

pembelajaran di kelasnya. Penelitian tindakan kelas bertujuan untuk mengembangkan strategi pembelajaran yang paling efisien dan efektif pada situasi yang alamiah (bukan eksperimen).

Prosedur dalam Penelitian Tindakan Kelas ini menurut model Stephen Kemmis dan Robbin Mc.Taggrat dengan model yang diperkenalkan oleh Kurt Lewin. Karena didalam satu siklus atau putaran terdiri dari empat komponen / tahapan antara lain, (Zaenal Aqib, 2007:22 ): Perencanaan (planning), Tindakan/ aksi (acting), Oservasi (observing), Refleksi (reflecting).

Subyek penelitian dalam tindakan kelas ini adalah siswa di SMP Negeri 2 Taluditi Kelas VIII semester genap Tahun Ajaran 2017/2018 dengan jumlah siswa 34 orang yang terdiri dari 22 laki-laki dan 12 perempuan. Penelitian ini direncanakan selama 3 bulan sejak bulan Desember 2017 sampai dengan Februari 2018 yang terbagi atas 2 siklus, masing-masing siklus terdiri atas 2 kali pertemuan (4x40 menit). Setiap akhir siklus diadakan refleksi untuk mengevaluasi pelaksanaan siklus tersebut dan melakukan perencanaan ulang dengan perbaikan tindakan untuk siklus berikutnya. Data penelitian diperoleh dari :

1. Data prestasi siswa yaitu nilai ulangan evaluasi sebelum tindakan / nilai pra siklus

2. Data tentang tingkat partisipasi siswa dalam mengikuti pembelajaran pada siklus I, siklus II

3. Data tentang hasil evaluasi setelah pembelajaran selesai baik pada siklus I dan siklus II

4. Data tentang sikap siswa terhadap penggunanaan model pembelajaran Make a Match

Sumber-sumber penelitian antara lain Nara sumber yaitu siswa, guru dan kolabolator, Peristiwa-peristiwa yang terjadi selama tindakan, Foto / gambar pada saat terjadinya pembelajaran. Tehnik yang digunakan dalam penelitian ini adalah Lembar observasi, Catatan di lapangan / pada waktu melakukan tindakan, Lembar pedoman wawancara, Lembar penilaian individu setelah mengikuti pembelajaran. Untuk mendapatkan data yang valid maka data yang terkumpul harus dianalisa, yang dikembangkan selama proses refleksi sampai proses penyusunan laporan. Tehnik analisa data yang digunakan adalah model alur, yaitu reduksi data, penyajian data dan penarikan kesimpulan (Milles \& Huberman 1989 dalam Aqib, 2007).

\section{HASIL PENELITIAN DAN PEMBAHASAN}

Sekolah yang menyelenggarakan pendidikan sejak tahun 2002, dibawah yayasan pendidikan Oxford Course Indonesia ini memiliki lingkungan fisik cukup baik, hal ini diamati dari cara mengatur dan memelihara ruang kelas, ruang-ruang kerja, perpustakaan, halaman sekolah dan ruang lain seperti toilet, mushola, dan kantin. Kerapian dan kebersihan ruang kelas selalu diperhatikan setiap hari. Ditinjau dari kuantitas dan kualitas guru, SMP Negeri 2 Taluditi mempunyai 12 orang guru. Sebagian besar guru telah mempunyai pengalaman mengajar selama kurang lebih 8 tahun.

Dengan berbagai kegiatan ekstrakurikuler tersebut diharapkan siswa bisa berprestasi di bidangnya masing-masing dan untuk meningkatkan prestasi siswa di SMP Negeri 2 Taluditi. Dalam observasi peneliti memperoleh catatan mengenai kondisi kelas dan belajar IPS siswa kelas VIII. Proses pembelajaran serta cara 


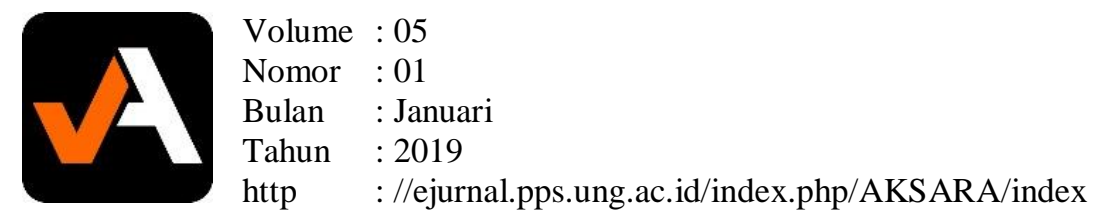

mengajar guru masih menggunakan model ceramah dan tanya jawab. Data dan hasil observasi yang dilakukan sebelum pelaksanaan tindakan, data kondisi awal aktivitas belajar menunjukkan presentasi 15,28\%. Data yang diperoleh dapat dijelaskan bahwa aktivitas belajar siswa masih rendah yaitu 15,28\%. Dari kondisi itu maka perlu diadakan suatu tindakan untuk mengatasi kondisi tersebut. Data hasil dari observasi yang diperoleh, peneliti mengamati cara mengajar guru sebelum pelaksanaan tindakan, didapatkan kesimpulan bahwa guru menggunakan model pembelajaran konvensional yaitu dengan ceramah dilanjutkan tanya jawab. Penggunaan model pembelajaran satu arah dan pembelajaran hanya terpusat pada guru mengakibatkan siswa kurang mandiri dalam belajar, sehingga mengakibatkan aktivitas belajar siswa yang rendah.

Dengan kondisi yang seperti ini, maka peneliti menawarkan untuk menggunakan model pembelajaran Make a Match guna untuk meningkatkan aktivitas belajar siswa pada mata pelajaran IPS. Penerapan model pembelajaran Make a Match diharapkan mampu mengatasi kondisi ini dan mampu meningkatkan aktivitas belajar IPS. Alasan dipilihnya model pembelajaran Make a Match karena teknik ini adalah siswa mencari pasangan sambil belajar mengenai suatu konsep atau topik, dalam suatu yang menyenangkan. Dengan demikian aktiviats belajar siswa juga akan lebih meningkat.

Pada awal pelaksanaan siklus I peneliti menemukan banyak hambatan dalam penerapan model pembelajaran Make a Match. Suasana pembelajaran tidak dapat dikendalikan karena sebagian siswa membuat gaduh saat proses belajar dan sebagian siswa masih bingung dengan langkah-langkah dalam model pembelajaran Make a Match, namun hambatan tersebut mendorong peneliti untuk terus berusaha membuat siswa paham dengan apa yang diterapkan oleh peneliti. Hasil yang diperoleh setelah dilaksanakan tindakan menyatakan bahwa aktivitas siswa dalam pembelajaran IPS masih belum mencapai indikator $>85 \%$. Pada siklus I ini diperoleh rata-rata aktivitas siswa adalah sebesar 51,17 \% dari 34 siswa, maka tindakan siklus II perlu dilakukan.

Uji Validitas, hasil tanggapan siswa terhadap penerapan model pembelajaran Make a Match. Data yang diperoleh pada siklus I berupa data aktivitas belajar siswa serta data observasi terhadap guru hasilnya dilakukan cros chek untuk mengetahui kevalidan data yang diperoleh. Cros chek dilakukan antara pelaksana tindakan sebagai observer dan siswa. Cros chek dengan observasi dilaksanakan dengan lembar berupa lembar aktivitas belajar siswa siklus I. Sedangkan cros chek yang dilakukan terhadap siswa yang dilaksanakan dengan menggunakan lembar tanggapan siswa siklus I dan dari hasil cros chek didapatkan hasil yang sama, sehingga dapat disimpulkan bahwa data yang diperoleh pada siklus I valid.

Tindakan kelas siklus II dilaksanakan setelah siklus I selesai dilaksanakan. Pada tahap ini kemungkinan ada perubahan yang merupakan perbaikan hasil evaluasi dari pelaksanaan siklus I. Dalam pelaksanaan siklus II siswa terlihat antusias dalam melaksanakan model pembelajaran Make a Match, hal ini terlihat dalam kesiapan siswa dalam menerima pelajaran. Dalam pelaksanaan siklus II aktivitas siswa lebih meningkat dibandingkan siklus I. Perubahan demikian bisa dilihat dengan adanya peningkatan aktivitas dalam proses pembelajaran. Sebagian besar siswa aktif mengajukan pertanyaan, mengemukakan pendapat, dan menjawab pertanyaan. Hasil siklus II yang diperoleh setelah dilaksanakan tindakan menyatakan bahwa aktivitas siswa mengalami peningkatan daripada siklus I, ini diperoleh rata-rata aktivitas siswa sebesar 85,30\% dari 34 siswa, maka siklus III tidaklah perlu dilakukan. 


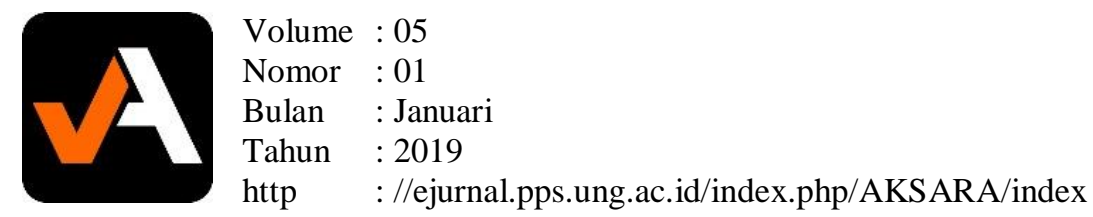

Pada proses pembelajaran siklus II tersebut mengalami peningkatan dikarenakan peneliti sebelumnya menjelaskan lebih rinci dan belajar dari pengalaman mengajar pada siklus I mengenai langkah-langkah penggunaan model dalam proses pembelajaran. Dalam hal ini peneliti melakukan perbaikan langkah-langkah pembelajaran yang dilakukan pada siklus I. Pelaksanaan siklus II ini tidak menemui hambatan yang berarti. Hal tersebut terbukti pada saat penggunaan model pembelajran Make a Match siswa cenderung lebih aktif jika dibandingkan dengan pelaksanaan siklus I.

\section{PENUTUP}

Dari penelitian yang dilakukan dengan dua siklus dimana tiap siklus dilakukan dalam dua kali pertemuan yang bertujuan untuk memperoleh data peningkatan aktivitas dalam pembelajaran IPS siswa. Hasil Penelitian menunjukkan bahwa sebelum tindakan diperoleh rata-rata tingkat aktivitas siswa sebesar 15\%. Pada siklus I tingkat rata-rata aktivitas siswa meningkat menjadi 51,17\%. Rata-rata aktivitas meningkat $36,17 \%$. Pada siklus II tingkat rata-rata aktivitas meningkat menjadi $85,30 \%$. Rata-rata aktivitas siswa dari siklus I ke siklus II meningkat menjadi 34,13\%. Hal ini berarti peningkatan aktivitas siswa mencapai indikator pencapaian yakni $85 \%$.

Berdasarkan data hasil Penelitian Tindakan Kelas (PTK) tersebut maka dapat disimpulkan bahwa dengan penerapan model pembelajaran Make a Match dapat meningkatkan aktivitas dalam pembelajaran IPS pada siswa kelas VIII SMP Negeri 2 Taluditi Tahun Ajaran 2017/2018. Hal ini karena model pembelajaran kooperatif tipe Make a Match (mencari pasangan) mengandung unsur permainan sehingga dapat meningkatkan aktivitas belajar siswa baik secara kognitif maupun fisik.

Sehubungan dengan hasil penelitian ini, peneliti mengemukakan beberapa saran: Penerapan pembelajaran model Think-Pair-Share perlu memperhatikan pemanfaatan waktu secara cermat dan hati-hati agar dapat mencapai sasaran yang diinginkan.

Apabila melaksanakan pembelajaran secara berkelompok, sebaiknya di samping memperhatikan kemampuan akademik, guru/peneliti hendaknya memperhatikan pula nilai-nilai sosial yang ada dalam kelas (selain suku dan jenis kelamin).

\section{DAFTAR PUSTAKA}

Depdiknas. 2006. Model Penilaian Kelas Kurikulum Tingkat Satuan Pendidikan SMP/Mts. Jakarta: Pusat Kurikulum Badan Penelitian dan Pengembangan.

Huda, Miftahul. 2013. Model-model Pengajaran dan Pembelajaran. Yogyakarta: Pustaka Pelajar.

Rusman. 2010. Model-model Pembelajaran Mengembangkan Profesionalisme Guru. Jakarta: PT Raja Grafindo.

Notoatmodjo, Soekidjo. 2003. Pendidikan dan Perilaku Kesehatan. Jakarta: PT Rineka Cipta. 


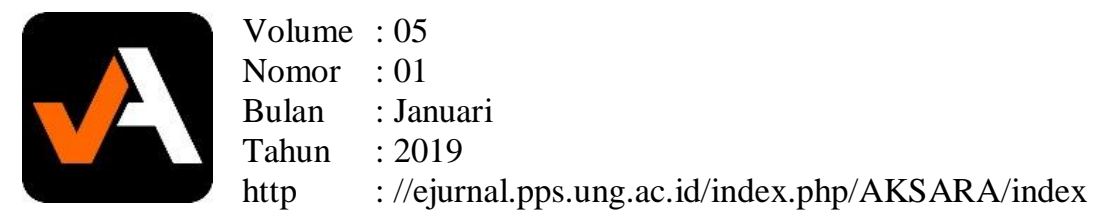

Sanjaya, Wina.. 2011. Strategi Pembelajaran Berorientasi Standar Proses Pendidikan. Jakarta: Kencana.

Sardiman. 2012. Interaksi \& Motivasi Belajar Mengajar. Jakarta: PT Raja Grafindo Persada.

Zainal Aqib. 2007. Penelitian Tindakan Kelas. Bandung: Yrama Widya. 